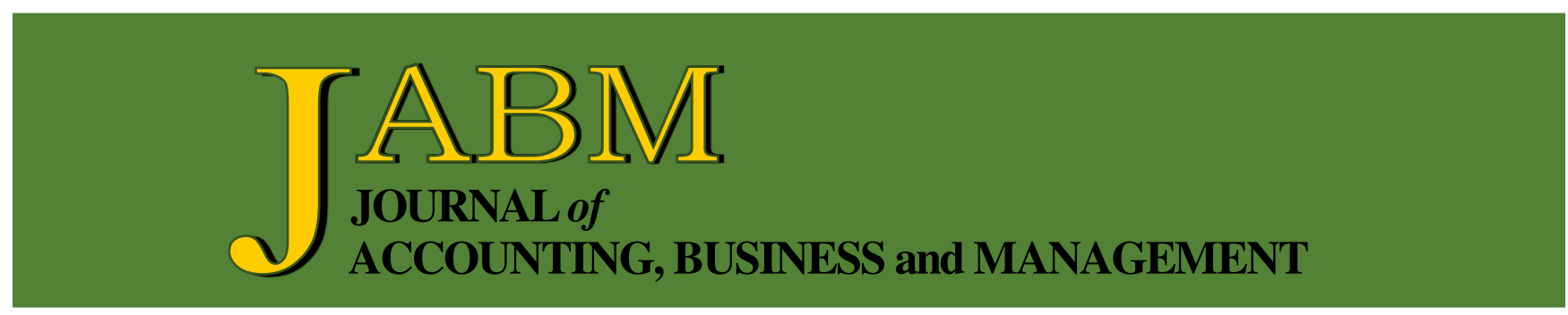

Life Insurance Companies: Determinants of Cost Efficiency and Profitability

Joseph Kwadwo Tuffour, Kenneth Ofori-Boateng, Williams Ohemeng, and Jane Kabukuor Akuaku

Subprime Crisis - A Corporate Acquisition Opportunity?

Vishal Srivastava, Sunder Ram Korivi, and Dipasha Sharma

Consequences of Weak Internal Controls Over Financial Reporting: Foreign versus U.S. Firms

Kathleen Bakarich and Devon Baranek

Impact of Organizational Commitment on Accounting Professionals' Performance: Case of Accounting Firms

Lassaad Abdelmoula and Sami Boudabbous

The Objectives of Sharia Management Accounting Information Reporting: Identification of Values and Characteristics

Sonhaji, Abdul Kadir Usri, and Hedher Tuakia

The Impact of Customer's Perception of the Practices of Corporate Social Responsibility on Purchase Intention

Doaa Abd El Samea and Ahmed Rashed

Corporate Financial Distress: The Impact of Profitability, Liquidity, Asset Productivity, Activity and Solvency

Karikari Amoa-Gyarteng

Determinant Factors of Social Cohesion and Inclusion of Street Vendors in Jakarta: Key Factor Surviving During Covid-19 Pandemic

Beti Nurbaiti 
Journal of Accounting, Business and Management (JABM) vol. 28 no. 2 (2021) 116-127

\title{
Determinant Factors of Social Cohesion and Inclusion of Street Vendors in Jakarta: Key Factor Surviving During Covid-19 Pandemic
}

\author{
Beti Nurbaiti*
}

\begin{abstract}
This study aims to analyze the determinants of one of the sub-dimensions of social capital, namely social cohesion and inclusion on street vendors (PKL) in DKI Jakarta, most of whom are migrants. The study was conducted using primary data from a survey of the masterplan PKL study in DKI Jakarta in 2021 in 5 municipal areas, namely North Jakarta, West Jakarta, Central Jakarta, South Jakarta, and East Jakarta. The survey was conducted on 1409 street vendors. The method used is quantitative using a questionnaire instrument, which is equipped with in-depth interviews. The results showed that during the pandemic, all street vendors experienced a decrease in turnover, income, and profits and needed to adjust their household expenses to survive. During difficult times, they rely on social capital in the form of social cohesion and inclusion, helping each other in terms of business development, business capital support, transfer of knowledge, and trade skills knowledge. This is supported by the results of the social cohesion and inclusion variable measurement model test that has been carried out.
\end{abstract}

Keywords: social cohesion and inclusion, urban informal sector, migrant, street vendors, DKI Jakarta.

\section{INTRODUCTION}

The existence of development inequality is the main cause of population migration, which flows from villages to cities. The process of industrialization and modernization that occurred in the village shifted the livelihoods of the residents because their agricultural land had been converted into factories, malls, and even golf courses. Although their agricultural land is still used as a plantation area such as oil palm, in general, their working area in agriculture is decreasing. On the other hand, the daily necessities of life continue to grow and cost money, forcing them to look for work in the city. Arriving in the city, these migrants are forced to enter the informal sector due to limited knowledge, skills, and capital, both trading capital and decent living capital.

Most of them work as kali lima traders/street vendors (PKL), either living/staying, or traveling/hawkers. While selling, they mostly use the land for public facilities in the city of Jakarta, such as sidewalks, city parks, and even green lanes because of limited capital to rent a proper place to sell. The difficulties in their lives do not stop there but have also gotten worse since the Covid-19 pandemic hit all parts of the world, including street vendors in DKI Jakarta. This can be seen from the decline in their quality of life as a result of the decline in income, turnover, and trading profits. During the pandemic, the number of buyers decreased drastically not only due to the implementation of community activity restrictions (PPKM) but also due to the decline

\footnotetext{
* Assistant Professor, Faculty of Economic and Business, University of Bhayangkara Jakarta, Indonesia. E-mail: bettysigit@gmail.com.
} 
in people's purchasing power. This is the background for conducting primary research related to the title of the article that has been stated by the author.

\section{LITERATURE REVIEW}

In the Indonesian economy, urban inequality is higher than rural inequality. Development concentrated in most of the large cities on the island of Java has resulted in these urban areas having higher capital-labor ratios and higher returns on skills than other parts of the country. Jakarta, a metropolitan city in Indonesia, has become one of the cities with the highest income inequality in the country. This is indicated by the presence of urban areas as the main determinant of internal migration in Indonesia where people migrate to large urban areas in Java, especially Jakarta. Migration is one of one's efforts to improve his standard of living, and not only affects the population size of an area but also has a significant influence on the socioeconomic aspects (Chotib \& Nurbaiti, 2018).

Internal migration dominates economic development in Indonesia with different development disparities between regions. Social capital and migration focus primarily on the importance of social capital for assisting migrants in destination areas. social capital affects the opportunity cost of migration (Burke, 2015). Once individuals move, the potential and actual benefits of their original social capital may diminish over time. That is, the benefits of the original social capital depreciate over time, and rates of depreciation may vary between communities. The opportunity cost of migration is correlated with individual capabilities but emphasizes the role that social capital plays in channeling that correlation. In other words, the presence of social capital can cause the opportunity cost of migration to be correlated with skills (Ridwan, 2016). The essence of social capital is the existence of networks, applied norms, and trust and solidarity between individuals in social entities. Social capital is very helpful in increasing the productivity of individuals and communities in carrying out daily activities such as working and trading and other social activities (Nurbaiti \& Chotib, 2020).

Social capital consists of two dimensions, namely: (1) the bridging dimension (inclusive) and (2) the bonding dimension (exclusive). The bridging dimension is defined as the level of trust that exists in the community to facilitate cooperation and coordination among community members, bring information by distributing valuable information related to work productivity, market potential, and winning the competition. Bridging social capital is the level of trust among community members regardless of their demographic background. It looks outward and includes people across different social circles, and is useful for connecting to external assets and disseminating information. Furthermore, there is the bonding dimension (exclusive), which is defined as the level of trust between individuals who have the same socioeconomic characteristics to improve business efficiency (business) with being outside the group. Bonding social capital is the level of trust among community members who share similar demographic characteristics; it looks inward and tends to strengthen the identity of exclusive and homogeneous groups, the existence of certain reciprocal relationships, mobilize solidarity, and form social, economic, and political collusion (Bongomin, 2020).

The social capital is included in 3 groups: (1) the input dimension, which includes group and network as well as trust and solidarity; (2) operational dimension, which includes collective action and cooperation as well as information and communication, and (3) implementation dimension which includes social cohesion and inclusion and empowerment (Östh et al., 2018). First, social cohesion is usually 
considered a broad concept, spanning several dimensions, and bearing the same weight. Typically, each definition includes two or more of the following attributes: the sense of belonging and active participation, trust, income distribution, equal opportunity, absence of barriers to social mobility, well-being, and social inclusion. Second, the notion of social cohesion is often associated with the narrower concept of social capital. Social capital represents an important but not sufficient condition for a society to be cohesive: social capital refers to groups or individuals whereas social cohesion is a holistic approach extended at the level of the whole society. Third, the challenge of defining social cohesion is often bypassed by focusing on conditions when social cohesion collapses, or when a society is not cohesive enough. Fourth, social cohesion often reflects a process rather than a condition itself both in terms of means and results (Grootaert et al., 2016). The term social cohesion is often used interchangeably with the term social capital. In fact, social cohesion, both interpersonal and intergroup, is similar to the notions of "bonding" and "bridging" in terms of social capital. Social capital is often seen as an asset at the individual level. The term social cohesion is more often used to emphasize the discussion of group attributes. The social capital literature includes many descriptions of how bonding in social capital can undermine social capital bridging by strengthening social divisions (Mpanje et al., 2018).

Social cohesion and inclusion are multidimensional constructs, and there must be a clear distinction between inter-individual cohesion and inter-group cohesion, which applies to various levels of analysis (Purnawati \& Ketut, 2019). the form of social cohesion can change over time, for example, from inter-group cohesion to interindividual within a certain group. social cohesion can be culturally specific. Social capital, social cohesion, and inclusion tend to rely on attitudinal measures rather than behavioral measures. Social cohesion cannot be separated from the influence of socioeconomic characteristics on individuals as social beings. Individual characteristics and social characteristics are special characteristics possessed by a person which are characterized by age, education level, income level, place of residence, and work performance, as well as communication behavior (Bravo, 2016).

Population and socioeconomic factors (such as education level, income, employment status, marital status, and so on) in relation to individual actions. Individual participation in organizing in the community. Measured by: (1) membership in the organization; (2) attendance intensity in the last 3 months; (3) participation in decision making; (4) the possibility of getting help from neighbors; (5) trust in residents in the community (neighbors), and (6) efforts to maintain trust among residents in the community. The characteristics of social inclusion include (1) access to affective support (through love and affection and friendship; through leisure activities and other forms of relaxation; (2) access to cognitive support (through advice, assistance with important life decisions). ); (3) access to material support (through assistance with specific physical assistance); (4) the identity of who provides affective support; (5) the identity of the cognitive support provider, and the identity of the material support provider (Chotib, 2014).

\section{RESEARCH METHODS}

The study was conducted for one month from 1-31 August 2020 in Jakarta area by taking primary data using a questionnaire instrument from 1409 respondents. The results of the field data were processed with Lisrel software. This process is carried out through 3 (three) stages, namely: (1) test the measurement model that includes the goodness of fit test, validity, and reliability test. The fit test can be seen in the goodness 
of fit index (GOFI) table where there are 9 indicators to show a good match (RMSEA, NFI, NNFI, CFI, IFI, RFI, Standardized RMR, GFI, and AGFI). For the match above, both (perfect fit) contain a degree of freedom $=0$, minimum fit function chi-square $=0$. The validity test can be seen from the standardized loading factor (SLF) value $\geq 0.50$, and the reliability test is said to be good if the construct reliability value $(\mathrm{CR}) \geq 0.70$, and variance extract $(\mathrm{VE}) \geq 0.50$. For further, (2) confirmatory factor analysis (CFA) test (Wijanto, 2008).

\section{RESULTS AND DISCUSSION}

The results of descriptive statistical data processing based on the respondent's profile can be seen in the image below:

Figure 4.1.

Field of Business and Type of Culinary Field

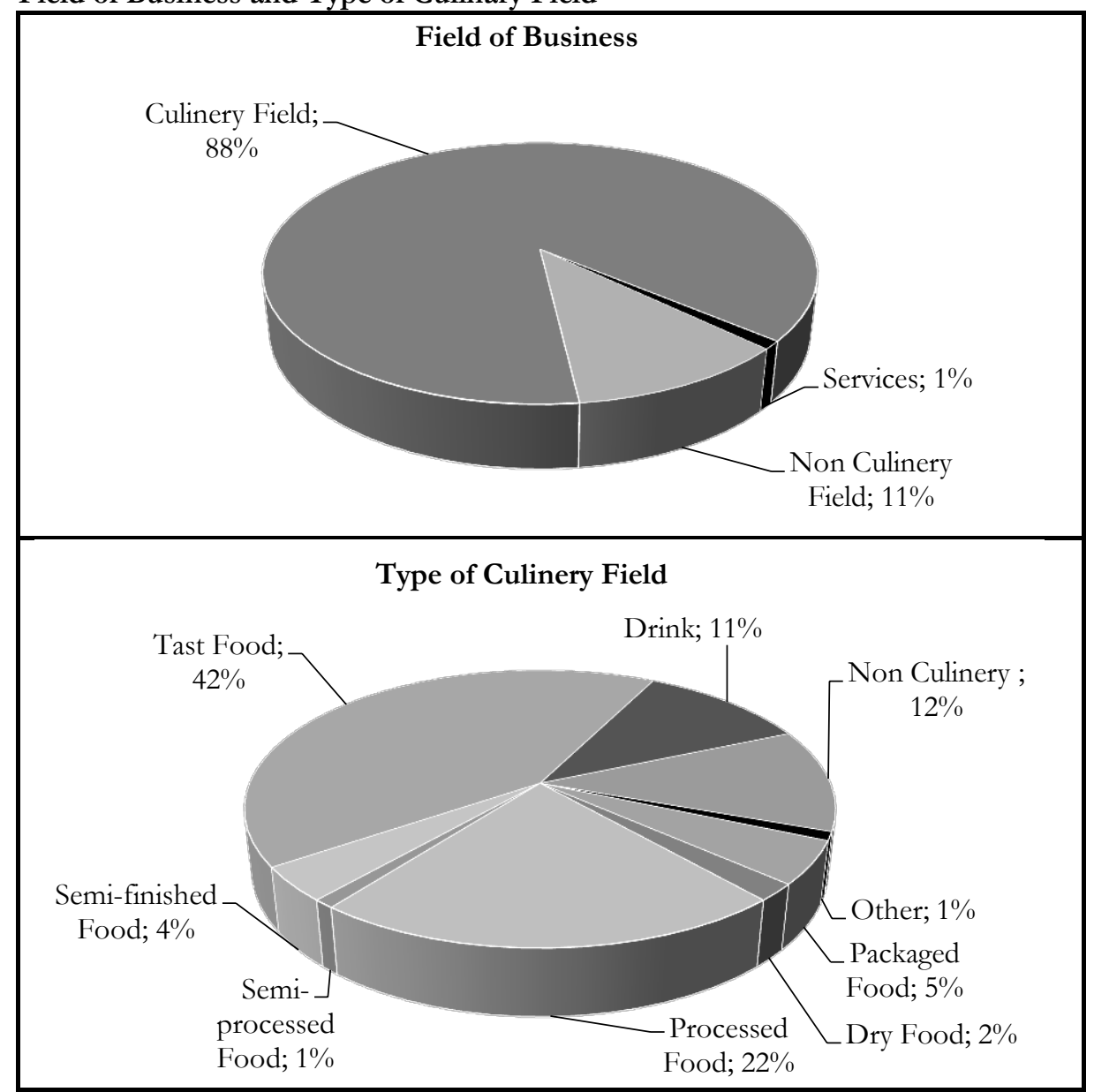

Based on Figure 4.1. above it can be seen that most of the street vendors as respondents trade in the culinary field as many as $88 \%$, the rest are non-culinary $11 \%$, and $1 \%$ services. If it is associated with the type of culinary merchandise is fast food. This is understandable because during the pandemic with restrictions on community interaction and even limited movement out of the house, the purchasing system is carried out online, including ordering food as daily necessities during the Covid-19 pandemic. 
Figure 4.2.

Respondent's Descriptive by Gender and Marital Status

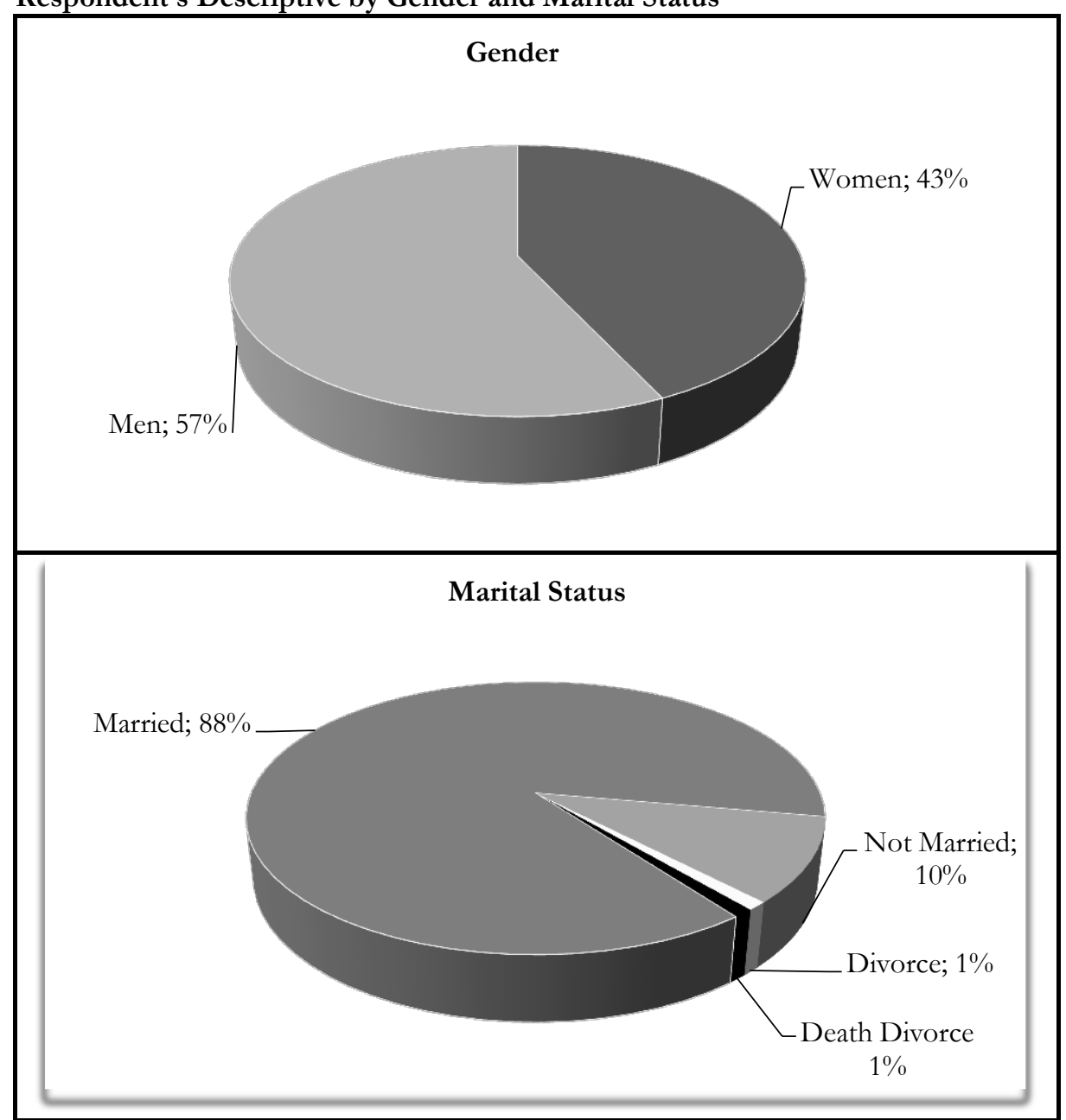

Referring to Figure 4.2., it can be seen that most of the street vendors are married or already have dependent children and wives in their families. In fact, not infrequently they also bear the burden of a large family, including their parents who live with them. Judging from the proportion of street vendors by gender, it is still dominated by men, although the proportion is not much different from women. This data shows that women have a bigger role and role in helping the household economy, especially in helping to find additional income during the Covid-19 pandemic by trading as street vendors.

Insert Figure 4.3. here.

Based on the data in Figure 4.3 above, it can be seen that most street vendors have junior high and high school education, very few have received a diploma or bachelor's education. This shows the fact that street vendors, some of whom are migrants from villages entering Jakarta, do not have sufficient knowledge and skills. However, most of them are recent migrants, where this group of migrants at least 5 years ago had settled in Jakarta and had a DKI Jakarta ID card. A small number of street vendors who are not residents of Jakarta do not have a DKI Jakarta ID card but live and sell in Jakarta. 
Figure 4.3.

Respondent's Descriptive by Education and DKI ID Card Ownership

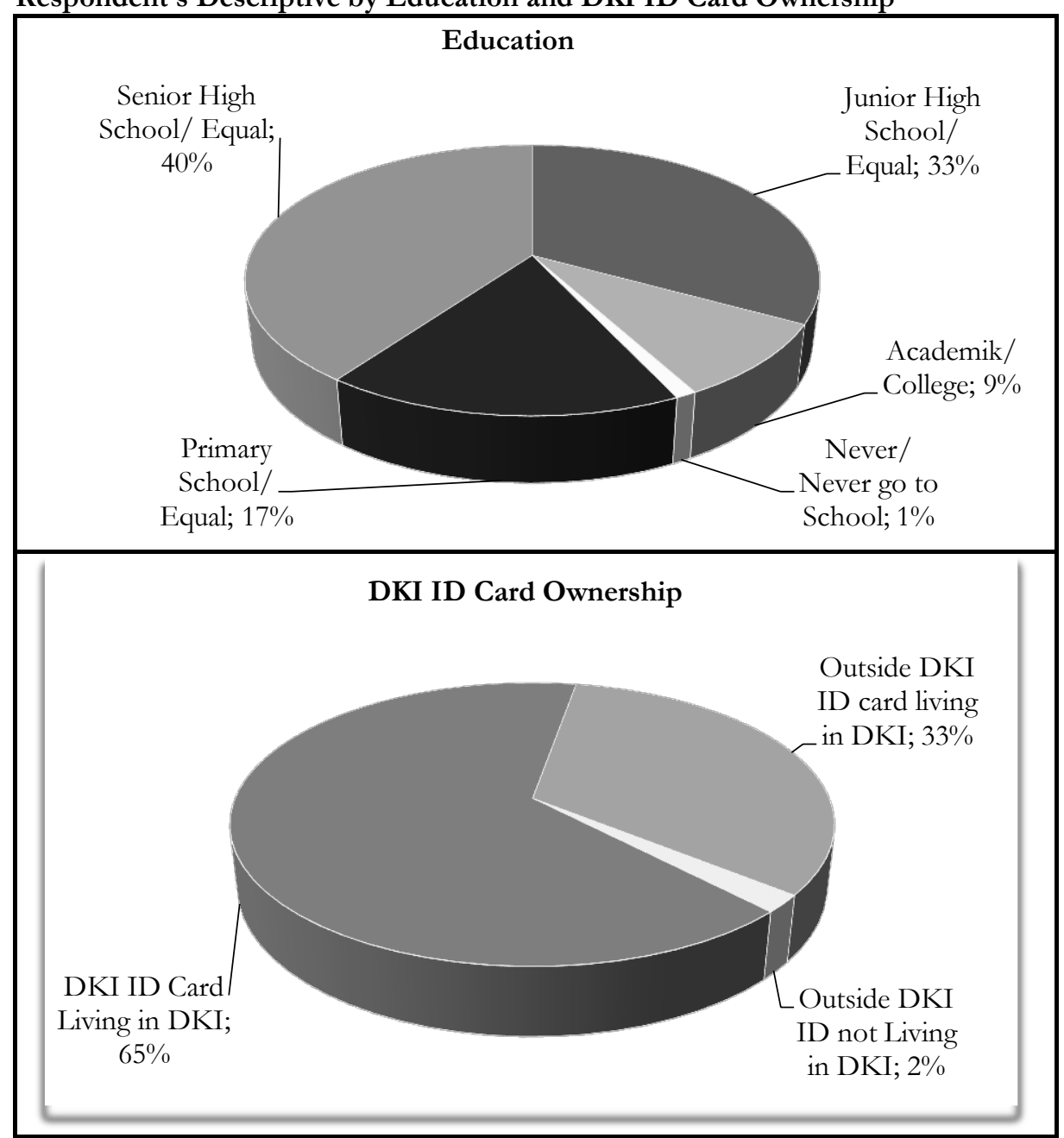

The income of street vendors has decreased significantly during the pandemic compared to before. This can be seen in the pie chart above, where before the pandemic street vendors who earned more than Rp. 5,000,000 were 32\%, while during the pandemic it fell to $20 \%$. The proportion of street vendors who experienced this decline shifted to the lower-income group, which was $>$ Rp. 3,000,000-Rp. 5,000,000 (before the pandemic 29\%, after the pandemic 34\%) and Rp. 1,000,000-Rp. 3,000,000 (before the pandemic 27\%, after the pandemic 34\%). This shows that the pandemic has a significant effect on the decline in the income of street vendors in general due to the large-scale social restrictions (PSBB) and the decreasing number of people leaving the house to avoid the spread of the Covid-19 outbreak. 
Figure 4.4.

Respondent's Income (During and Before Pandemic Covid-19)

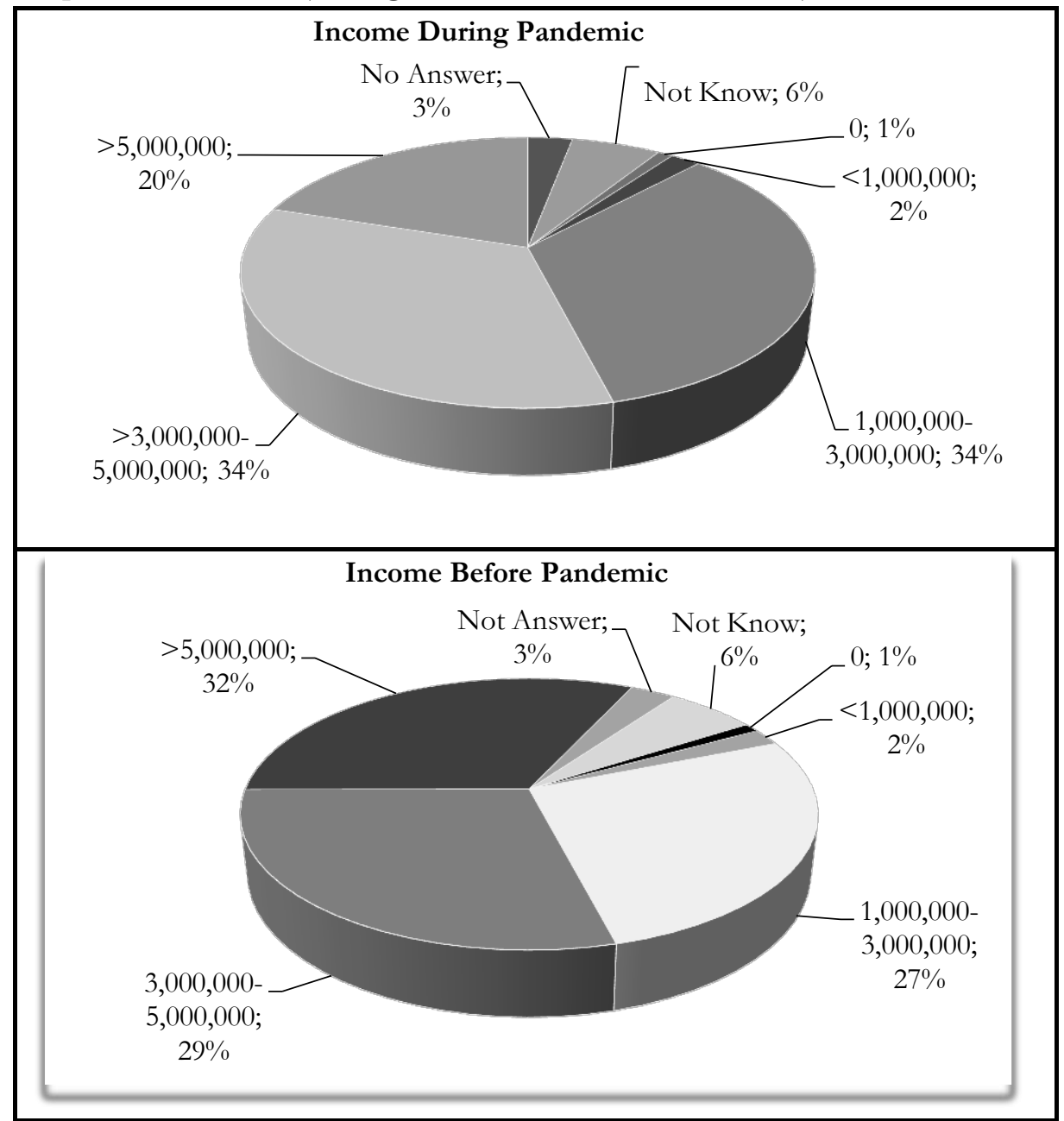

Figure 4.5.

Respondent's Spending (During and Before Pandemic Covid-19)

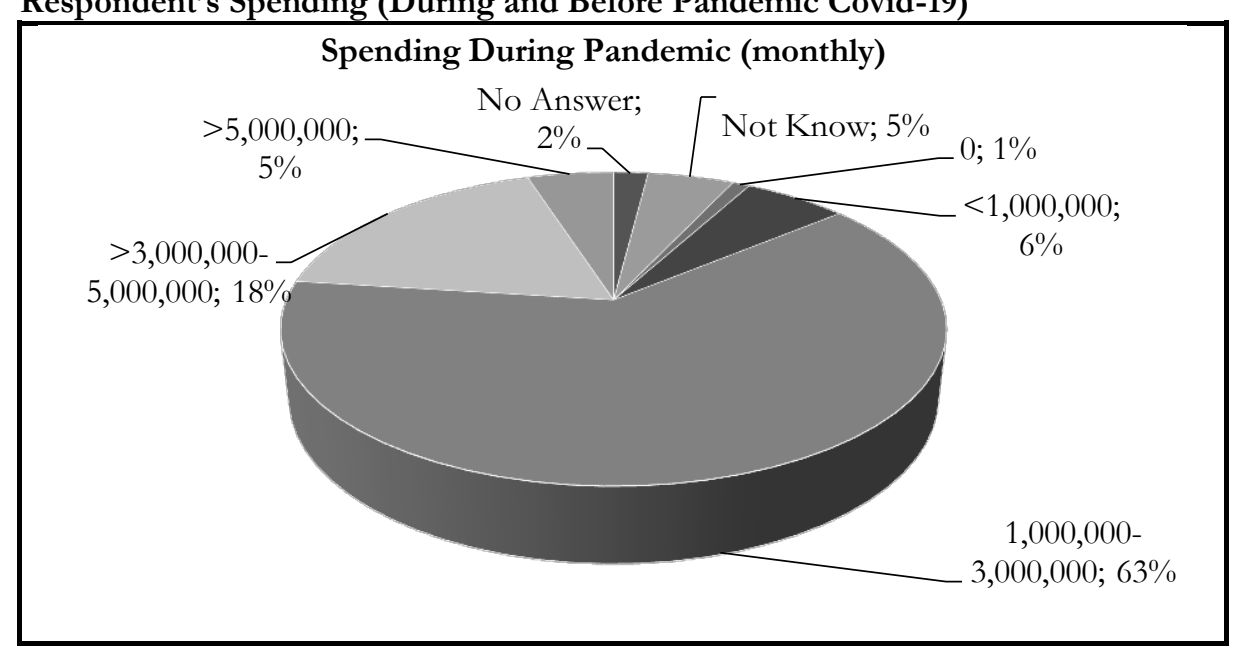




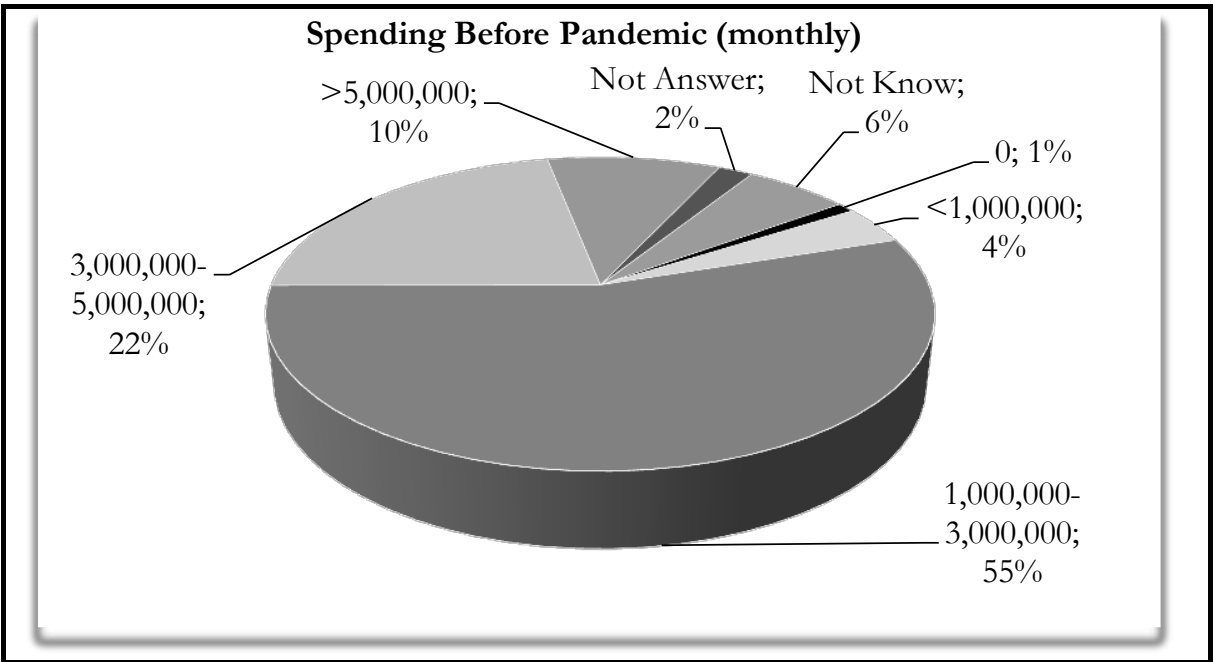

PKL spending, especially in meeting household needs during the pandemic, is different from before the pandemic. This condition is also very dependent on the income they get, where expenses before the pandemic were greater than Rp. 5000,000 had a proportion of $10 \%$ while during the pandemic it decreased to $5 \%$. This condition is also almost the same as the previous explanation, that they save expenses to $>$ Rp. 3,000,000-Rp. 5,000,000 (before the pandemic 22\%, after the pandemic 18\%) and Rp. 1,000,000-Rp. 3,000,000 (before the pandemic 55\%, after 63\%).

Figure 4.6.

Respondent's Net Profit (During and Before Pandemic Covid-19)

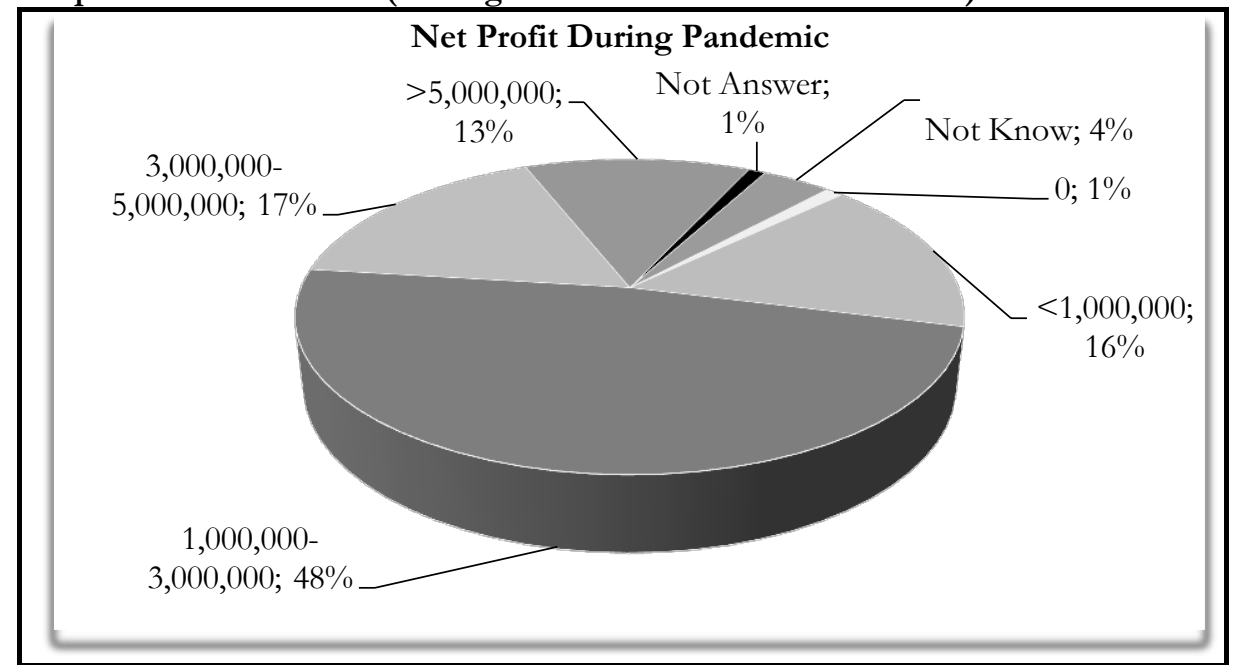

Insert Figure 4.6. (Net Profit Before Pandemic) here.

The net profit of street vendors also decreased in two different conditions, namely before and after the pandemic. Before the pandemic, the net profit of street vendors $>$ Rp. 5,000,000 had a proportion of $29 \%$, while after the pandemic it was $13 \%$. PKL profits shift in the lower value range, which is > Rp. 3,000,000Rp. 5,000,000 (before the pandemic 21\%, after the pandemic 17\%) and Rp. 1,000,000Rp. 3,000,000 (before the pandemic 33\%, after the pandemic 48\%). This is due to a pandemic that has made the net profit of several street vendors decrease in the range of 
Rp. 1,000,000-Rp. 3,000,000. So most of the street vendors are shifted in the lower range (Rp. 1,000,000-Rp. 3,000,000).

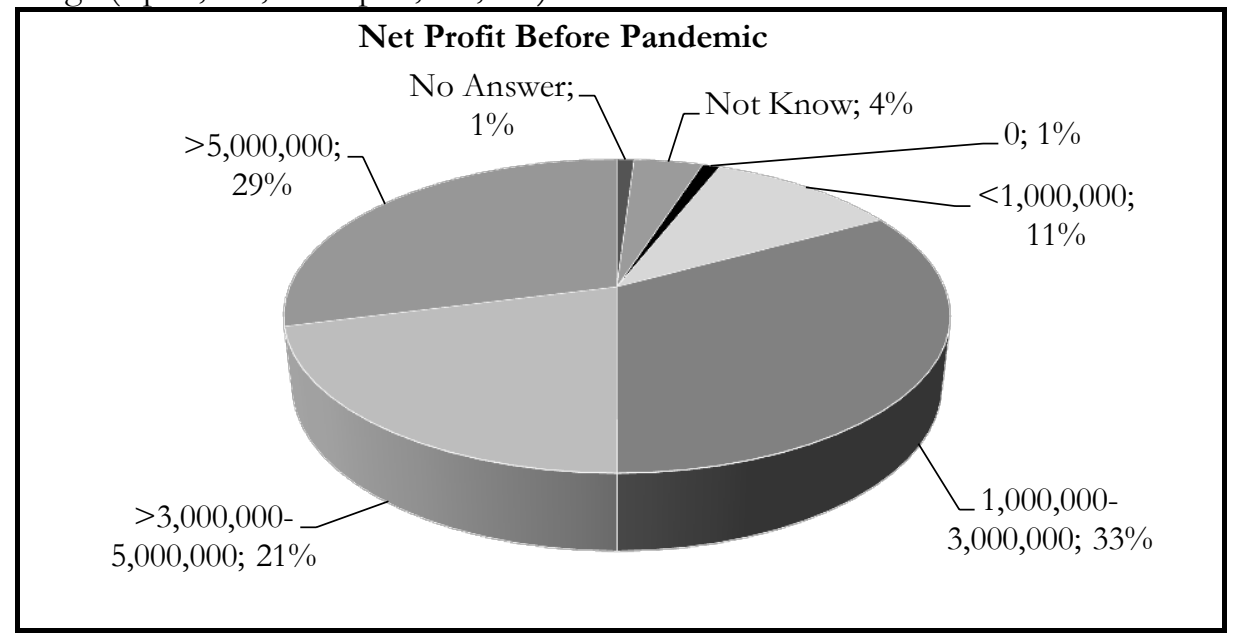

Based on the measurement test data processing, the confirmatory analysis (CFA) test and the structural model test/research hypothesis test can be seen in the description below:

Figure 4.7.

Path Diagram Variable Social Cohesion and Inclusion (SCAI) (Standardized Solution)

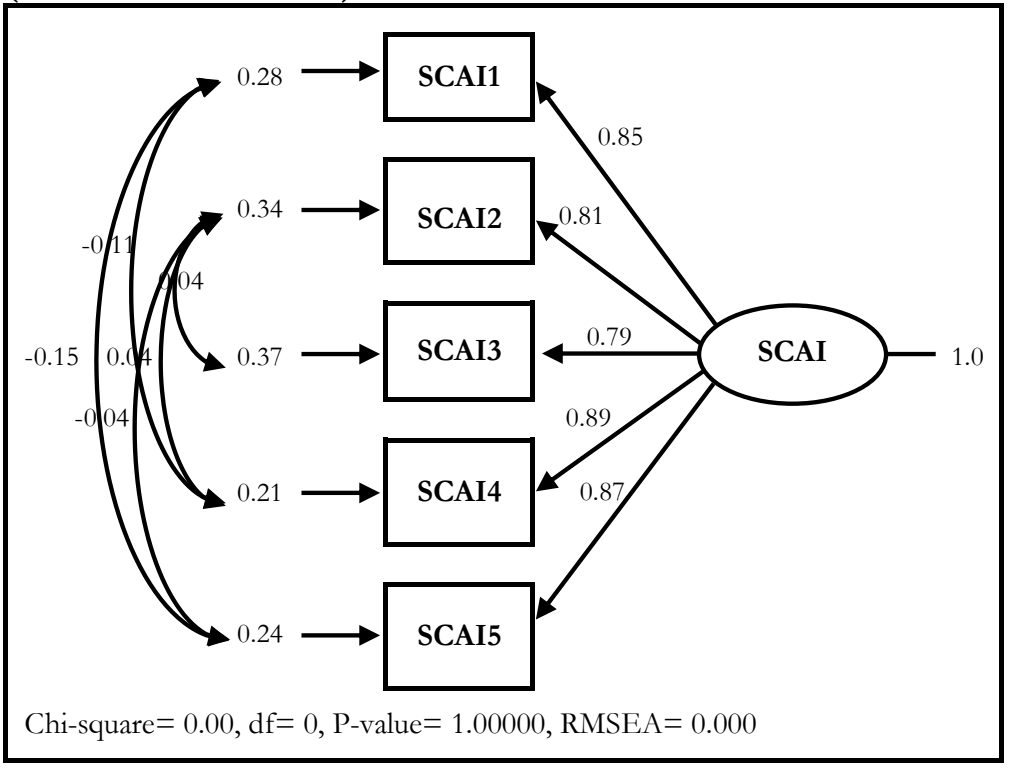

Table 4.1.

Goodness of Fit Test Results Social Cohesion and Inclusion (SCAI)

Degree of freedom $=0$

Minimum fit function chi-square $=0.00(\mathrm{P}=1.00)$

Normal theory weighted least square chi-square $=0.00(\mathrm{P}=1.00)$

Satorra-Bentler scaled chi-square $=0.00(\mathrm{P}=1.00)$

The model is saturated, the fit is perfect!

Conclusion: all variables observed in the WELF latent variable have a very good fit (perfect fit), the data support the research model. 
Table 4.2.

Validity and Reliability of Social Cohesion and Inclusion (SCAI)

\begin{tabular}{cccc}
\hline $\begin{array}{c}\text { Latent Variable/ } \\
\text { Observed Variable }\end{array}$ & $\begin{array}{c}\text { Standardized Loading } \\
\text { Factor (SLF) }\end{array}$ & Error & Information \\
\hline SCAI1 & 0.85 & 0.28 & Good Validity \\
SCAI2 & 0.81 & 0.34 & Good Validity \\
SCAI3 & 0.79 & 0.37 & Good Validity \\
SCAI4 & 0.89 & 0.21 & Good Validity \\
SCAI5 & 0.87 & 0.24 & Good Validity \\
\hline Conclusion goodness: all variables have good validity and reliability, with values \\
CR $=0.93$, VE $=0.71$.
\end{tabular}

All measurement results of the 5 observed variables from the latent variable SCAI are valid because the SLF value $>0.50$ with the highest order of SLF values to the low are SCAI4, SCAI5, SCAI1, SCAI2, and SCAI3. From the SCAI latent variable measurement chart below sequentially based on the highest SLF value. It can be seen that the convenience of being in groups in developing a business is the most important and crucial thing for street vendors in surviving in the pandemic era (SCAI4). Furthermore, street vendors assess that family/relatives provide benefits in developing a business (SCAI5). In addition to these two things, family/relatives support business capital for street vendors, most of whom do not have access to banks or formal financial institutions (SCAI1). In terms of trade/business knowledge skills, street vendors get them from family/relatives from generation to generation (SCAI2). To overcome daily difficulties in developing a business, street vendors share tasks with their relatives (SCAI3).

Table 4.3.

Determinant Factors of Social Cohesion and Inclusion (SCAI)

\begin{tabular}{clccc}
\hline No. & \multicolumn{1}{c}{$\begin{array}{c}\text { Questionnaire } \\
\text { Statement }\end{array}$} & $\begin{array}{c}\text { Std. Loading } \\
\text { Factor (SLF) }\end{array}$ & Error \\
\hline 1. & $\begin{array}{l}\text { Family/relatives provide comfort as a group in } \\
\text { developing a business (SCAI 4) }\end{array}$ & 0.89 & 0.21 \\
2. $\quad \begin{array}{l}\text { Family/relatives provide benefits in terms of developing } \\
\text { a business for me (SCAI 5) }\end{array}$ & 0.87 & 0.24 \\
3. $\quad \begin{array}{l}\text { My family/relatives support me in terms of business } \\
\text { capital (SCAI 1) }\end{array}$ & 0.85 & 0.28 \\
4. $\quad \begin{array}{l}\text { My family/relatives have given me support in terms of } \\
\text { trade/business skills that have been passed down from } \\
\text { generation to generation (SCAI 2) }\end{array}$ & 0.34 \\
Family/relatives provide support sharing tasks together \\
to develop the business (SCAI 3)
\end{tabular}

Social cohesion is described in various ways as "emotional bonds among community members", "local patterns of working together" and "the glue that binds people together, the promotion of harmony, a sense of belonging to the community, and the degree of commitment to promoting the common good. general". Discussions of social cohesion emerge in the analysis of the causes and consequences of social upheaval, violence, misallocation of aid, sustained poverty, low or negative economic growth, and the failure to bring about prosperity from market-oriented economic reforms.

This phenomenon occurs in the PKL group in Jakarta based on the results of the PKL master plan survey in DKI Jakarta in 2021. In maintaining the economic condition of their families, the PKL sells using family and kinship networks. This helps 
them get comfortable to develop their business in groups, get capital, trade skills, and share tasks in trading to survive during this pandemic.

Social cohesion as one of the dimensions of social capital is productive, refers to the behavior and attitude attributes of a community, which is based on geographical entities that share the same fate. Inter-individual social cohesion is obtained from observations that show differences in various individual groupings in the ability and handling of certain collective action problems, this can be seen in Table 4.3. Social solidarity, social interaction, and social cohesion cannot be separated from the influence of socio-economic characteristics on individuals as social beings. Individual characteristics and social characteristics are special characteristics possessed by a person which are characterized by age, education level, income level, place of residence, and work performance, as well as communication behavior. Population and socioeconomic factors (such as education level, income, employment status, marital status, and so on) in relation to individual actions are also important in the context of social cohesion and inclusion.

On the other hand, social inclusion is participation in the traditional/simple economy, including a set of items measuring the participation of both individuals and households in the production and exchange of resources. Social inclusion is often expressed in unity with social cohesion, which is a non-monetary system of production and exchange where social and economic value can be achieved in the street vendor community.

Social capital is defined as the collective relationships (social cohesion and inclusion) within social networks and the value of all tangible and intangible resources embedded in those networks. Broad social capital is said to have a significant positive impact on entrepreneurial success, in part because dimensions of cognitive social capital, such as trust, reciprocity, and togetherness are expected to enhance cooperation among network ties. With mutual trust, they exchange ideas, information, trading techniques, to lend capital (without access to banking), so that street vendors can survive even in difficult conditions.

\section{CONCLUSION AND SUGGESTIONS}

Social capital is the level of public trust that allows cooperation in productive economic relations, and this trust comes from three sources: 1) long-term social relations, 2) norms of social behavior, and 3) community enforcement. To cooperate in economic relations, each actor needs to show repeated cooperation in social relations, or the actors need to have norms of social behavior. Once a community has a common set of norms, trust can develop. Because the economic activity is an important part of social life, the welfare of the community is highly dependent on the level of trust attached to the community. This happened to the street vendors community in Jakarta. They have strong ties based on kinship in the same hometown, and there are still extended family ties. Social capital also shows that there is an element of mutual trust between individuals in the community which originates from: 1) repeated social interactions, 2) norms of social behavior, and 3) community enforcement. Thus, social capital determines the performance of a business or business and the interactions in it.

Social capital has been shown to have a positive relationship with a broad range of social and economic variables but has been studied primarily from a consumer perspective, for example, its effects on economic development as well as household income. For this reason, the local government in this case the Department of Industry, Trade, and Cooperatives and Small and Medium Enterprises of DKI Jakarta needs to 
provide guidance and empowerment to street vendors based on a community/group approach. This can be done in coaching in the form of revolving capital assistance between PKL groups, where the allocation, use, and supervision involve community leaders who are respected by the PKL group as a control function for the common good. Social capital is an intangible asset and plays an important role in driving economic activity through selling street vendors, as well as helping to survive in difficult times because there is mutual fortune sharing, market/customer information sharing, which is automatically done because of a sense of trust and togetherness.

\section{REFERENCES}

Bongomin, G. O. C., Woldie, A., \& Wakibi, A. (2020). Microfinance accessibility, social cohesion, and survival of women MSMEs in post-war communities in subSaharan Africa: Lessons from Northern Uganda. Journal of Small Business \& Enterprise Development, 27(5), 749-774. Https://doi.org/10.1108/JSBED-12-20180383.

Bravo, A. P. T. (2016). Three essays analyzing the role of social capital on individual and firm decision making. Unpublished Doctoral Dissertation, Purdue University, Indiana, USA.

Burke, P. (2015). Sejarah dan teori sosial (2nd ed., pp. 148-162). Jakarta: Yayasan Pustaka Obor Indonesia.

Chotib. (2014). Dampak mobilitas ulang alik terhadap kohesi sosial para pekerja di komunitas perumahana Depok. Disertasi Doktor, Program Pasca Sarjana, Fakultas Ilmu Sosial dan Ilmu Politik (FISIP), Universitas Indonesia Jakarta.

Chotib \& Nurbaiti, B. (2018, January). Are migrant workers in DKI Jakarta more welfare than non-migrants?: A data analysis of national social and economic survey (Susenas) 2013. Journal of Strategic \& Global Studies, 1(1), 15-28. Https://doi.org/10.7454/jsgs.v1i1.1001.

Grootaert, C., Narayan, D., Jones, V. N., \& Woolcock, M. (2016). Measuring social capital: An integrated questionnaire. World Bank Working Paper (no. 18), Washington, DC, USA. Https://openknowledge.worldbank.org/handle/10986/15033.

Mpanje, D., Gibbons, P., \& McDermott, R. (2018). Social capital in vulnerable urban settings: An analytical framework. Journal of International Humanitarian Action, 3(4), $1-14$.

Nurbaiti, B., \& Chotib. (2020). The impact of social capital on welfare: The evidence from urban informal sector in East Flood Canal (Bkt), Jakarta. IOP Conference Series: Earth \& Environmental Science, 436, 1-8. Doi.org/10.1088/17551315/436/1/012004.

Östh, J., Dolciotti, M., Reggiani, A., \& Nijkamp, P. (2018). Social capital, resilience and accessibility in urban systems: A study on Sweden. Networks \& Spatial Economics, 18(2), 313-336. Https://doi.org/10.1007/s11067-017-9375-9.

Purnawati, I. G. A., \& Sudibia, I. K. (2019). Social capital-based women empowerment to improve business performance. South East Asia Journal of Contemporary Business, Economics \& Law, 18(5), 166-173.

Ridwan, E. (2016, August). Essays on microfinance, entrepreneurship, and social capital in developing economies. Doctoral dissertation, Department of Economics, Indiana University, Bloomington.

Wijanto, S. H. (2008). Structural equation modelling dengan Lisrel 8.8 konsep dan tutorial. Yogyakarta: Graha Ilmu. 